\title{
Chapter 20 \\ Uppony Mountains: High Geomorphological Diversity Within a Small Area
}

\author{
Gábor Demeter and Katalin Szalai
}

\begin{abstract}
Merely of 454 m maximum elevation, the geologically and geomorphologically diverse and still dynamic Uppony Mountains is relatively rich in geomorphic features (caves, pseudocaverns, gorges, horsts, scarps, landslides, karren, natural outcrops) created by diverse processes (valley incision, derasion, mass movements, karst formation, periglacial, pedimentation). This small mountainous area with its intricate geological structure is ideal either for field investigations in order to obtain broader knowledge on the evolution of NorthHungary or to study both convergent and divergent evolution of forms generated on different rocks. Using a comparative approach, with an outlook to its environs, the quantification and numeric analysis of morphometric and lithological features combined with the traditional descriptive geomorphic approach promotes a better understanding of the area so important in the paleoenvironmental, paleogeographical reconstruction of North-Hungary.
\end{abstract}

Keywords: Paleozoic massif • Piedmont • Imbrication • Gorges • Landslides • Caverns

G. Demeter Institute of History, Hungarian Academy of Sciences, H-1014 Budapest, Országház út 30. E-mail: demeter.gabor@btk.mta.hu

K. Szalai Department of Tourism, Kodolányi János University of Applied Sciences, H-8000 Székesfehérvár, Fürdő út 1. E-mail: szalaikaty@uranos.kodolanyi.hu

\subsection{Introduction}

The Uppony Mountains of $240 \mathrm{~km}^{2}$ area are located in northeastern Hungary, in the Bükk Mountains northern foreland. It is mainly composed of slightly metamorphosed Paleozoic siliciclastic rocks and limestones with distant Alpine contacts, surrounded by semiconsolidated Neogene marine sediments. Its uniqueness is primarily due to the particular geology: both karstic and non-soluble, as well as highly diagenized and semi-consolidated sediments occur in the area. This geology induced diverse geomorphic processes (valley incision, derasion, mass movements, karst formation, periglacial), which created a variety of landforms (small caves, non-karstic pseudo-caverns, scarps, bedrock outcrops, rock crags). The folded-imbricate structure, with the south-easterly dipping reverse faults of the PaleoMesozoic massif (Pelikán 2005), resulted in scarps of different resistance to weathering and formation of fascinating cliffs. Owing to the imbricate structure, the buried Paleozoic rocks of the neighbouring Bükk Mountains to the south (composed of Mesozoic limestone-nappes with southern vergence) can be studied here exposed on the surface. Along the abundant fault lines 
tectonically preformed, asymmetrically incised valleys and gorges were formed exposing the second oldest (Late Ordovician-Permian) rock assemblage of the uplifted continental floor in Hungary and thus creating an opportunity for paleoenvironmental reconstruction. The preserved Neogene cover and the traceable erosion surfaces indicate well-dated transgression and exhumation periods. Thus, the post-sedimentary (orogenic) geomorphic history of the mountains can also be well detected. The origin of landforms, the effects of selective denudation on hard and loose rocks, slope evolution and downwearing processes can be studied within a few kilometres' distance (Fig. 20.1).

\subsection{Geological and Geographical Settings}

The Uppony Mountains are bordered by the Tardona Hills (E), the Bükk Mountains (S), the Ózd-Egercsehi Basin (W), the Vajdavár Hills (NW) and the tectonically preformed valley of the Sajó river (N). Located along the Darnó Fault Zone, it is one of the structurally most complicated regions of Hungary. It consists of two main parts. The $15 \mathrm{~km}^{2}$ core area (massif) is a horst dominantly characterized by Paleo- and partly by Mesozoic rocks, with remnants of Tertiary marine molasse sediment caps on the surface proving former transgression, subsequent exhumation, and a 400-m uplift since the Late Miocene (Pannonian). In the north the Paleozoic rocks were thrust over the Oligocene and Lower Miocene foreland (Fig. 20.2), while in the south there is a complicated relationship with the rock formations of the Bükk Mountains along the Nekézseny reverse fault (Kovács 1994). To the west and the east the Paleo-Mesozoic core is buried under Tertiary littoral-paralic sedimentary series (Fig. 20.2). Similar rocks also occur beyond the Sajó River (Szendrö-Rudabánya Mountains and Putnok Hills), but with different scenery. As attested by the rocks of various age and origin eroded to similar elevations, both the massif and its surroundings had once constituted the northern Bükk piedmont, which was dissected by valley regression. Today only ridges of $350 \mathrm{~m}$ and 420-450 m elevation indicate the existence of former planation surfaces. In addition to periodically renewed uplift, selective denudation also caused differences in the height of ridges composed of various rocks (Demeter and Szabó 2008a).

Compared to the adjacent areas, the unit represents an upthrown block exposing the rocks of the basement and separates the Eastern and the Western Borsod Coal Basin from each other. The structure is dominated by folded 'slices' of NNW vergence dismembered along reverse faults (Kovács 1994). In addition to its different geology, the Paleo-Mesozoic Uppony Mountains with steeper slopes and deeper (but not graben-type) valleys, also contrasts geomorphologically with its younger surroundings (Szalai 2004). The mountains belong to the catchments of the Csernely and Bán streams, the tectonically preformed, epigeneticantecedent valleys of which expose both old resistant rocks and young unconsolidated deposits (Fig. 20.1).

There is a cold and moderately arid continental climate in Uppony, with slightly less hours of sunshine $(1850 \mathrm{~h})$ and lower annual average temperature $\left(8.5^{\circ} \mathrm{C}\right)$ than common in Hungary. The average annual precipitation does not exceed $650 \mathrm{~mm}$, and the dominant vegetation is oak and birch forest. The gorges, however, present particular microclimatic conditions.

The Lázberc Landscape Protection Area, although established with the primary purpose to protect the drinking water basis of the Lázbérc reservoir (an artificial lake formed by impounding the valley of Bán stream) in 1975 (Fig. 20.3), bears a range of interesting geological, geomorphological and cultural sites, including the Damasa and Uppony Gorges and the Rágyincs valley, which are presented here in detail.

\subsection{Geological and Geomorphic Evolution}


The rocks of the Uppony Mountains are of regional significance for the evolution of the Carpathian Basin. Surrounded by Rudabánya-type Triassic and Lower Miocene sediments along the Uppony reverse fault to the north and by the Upper Permian-Lower Triassic rocks of the Bükk Mountains in the south along the Nekézseny reverse fault (Schréter 1945), the Uppony block is considered to be part of the Darnó Fault Zone (Péró 1997). Its imbricate structure with NNW vergence is marked by steep reverse faults of the Paleozoic rocks thrust over younger formations (Fig. 20.2) - also confirmed by the elongated NE-SW tracts. However, due to strong tectonics that rearranged the position of rocks the identification of the original settings is difficult. The imbricate structure (Fig. 20.4) had formed prior to the Upper Cretaceous (Alpine Orogeny), as the Nekézseny Conglomerate from this period in the SE part of the mountain settles discordantly on the underlying strata. Although the Variscan (Hercynian) Orogeny played a crucial role in the deposition of sedimentary units, the metamorphism of the Paleozoic sediments (foliation) took place during Alpine movements (Kovács 1994; Árkai et al 1982) (Fig. 20.4).

During the first sedimentation cycle (from the Late Ordovician to the Variscan Orogeny) sands were deposited followed by radiolarites, indicating the deepening of the sedimentary basin below the carbonate compensation level (known worldwide as Silurian euxinic facies). Subsequent tholeiitic basalts represent open marine conditions with a rift valley. The Devonian limestones were deposited on carbonate platforms, while the subsequent flysch-like sediments of the Carboniferous Lázbérc Formation are composed of the reworked terrestrial material of the mountains in the north, uplifted during the Variscan Orogeny. The following shallow marine molasse unit (lydites and calcareous sandstones of Mályinka Formation) represents the closing of the Paleo-Tethys and the end of the first sedimentation cycle (Budai and Konrád 2011). The black Permian Nagyvisnyó Limestone on the fringe of the mountains deposited in poorly aerated lagoons, rich in organic material, also indicates regression (as seen in the Mihalovits quarry).

According to the paleogeographical reconstruction of the Carboniferous (Hercynian Orogeny), the Uppony Mountains, located on the margin of the ALCAPA plate of African origin (Pelso Unit), was linked to the Carnic Alps and the Graz Paleozoic. While the Gemer Carboniferous in the north represents a terrestrial lowland accumulation series with the crystalline rocks of the Western Carpathians in the background, the Lower Paleozoic sequence of the Uppony block is built up of coastal and continental shelf sediments (Péró 1997).

The shallow marine carbonate sediments of the opening Tethys - introducing the second sedimentation cycle - begin with remnants of the Triassic Gutenstein Limestone. In the Cretaceous, during the Carpathian Orogeny, an imbrication process took place resulting in tracts elongated in northeast-southwest direction. The elevated thrust sheets were then subject to erosion and the reworked and transported material was cemented into coastal conglomerate (Nekézseny Conglomerate Formation), a correlative sediment (exposed in outcrops as well). In the Oligocene regression was followed by a transgression from the northeast induced by the subsidence of the floor in the northern foreland of the Carpathians, but the deposited material (up to $800 \mathrm{~m}$ thickness) was subsequently eroded from the Uppony Mountains.

During the Neogene three major transgressions affected the area. The first arrived from the southeast during the Ottnangian-Carpathian (17 Ma ago). Under Mediterranean conditions cross-bedded sand dunes, lidos and swampy lagoons developed with decreased salinity and abundant littoral (Taxodium) forests. These were buried by the transgressions generating 200 $400 \mathrm{~m}$ thick coal seams under anoxic circumstances (Borsod Coal Basin), which are missing from the uplifted massif itself. Another transgression reached the peripheral zone of the mountains 15 million years ago and deposited the Badenian Clay Formation of clay marl 
indicating deeper shelf and open marine conditions (Püspöki 1998), exposed in the Damasa Gorge. Subsequent intensive uplift removed most of the Badenian sediments from the Tardona Hills and the Uppony massif. The third and smallest transgression followed in the Sarmatian (13 Ma ago). By then many klippen did exist and were exposed to marine abrasion, as affirmed by erosion discordance in Miocene sediments lying directly on Permian rocks in the Mihalovits quarry at Nagyvisnyó. Under Mediterranean conditions rivers removed gravels of metamorphosed Paleozoic rocks and Gemer-type Mesozoic limestones (Sajóvelezd Beds) from uplifting areas and redeposited them in the Uppony Mountains (Fig. 20.2). Limestone gravels prove the temporary exhumation of the Bükk Mountains and the post-Sarmatian formation of the tectonic valley of Bán which separated the Bükk, the Tardona Hills and the Uppony Mountains from each other (Hevesi 1986, 2006). With the Sarmatian tectonic movements andesitic volcanic activity also intensified (Dubicsány Andesite Formation).

During the so-called 'Miocene geomorphic inversion', former sedimentary basins became uplifted, while ancient mountains subsided and seas retreated. The northern Bükk foreland with the Uppony Massif was elevated to $350-450 \mathrm{~m}$. The former northeastern and latter northwestern rotational upthrust of the Bükk determined the direction of present-day epigenetic-antecedent incised valleys (Csernely and Bán streams), characterised by captures, exposing the underlying older rocks. In the Pannonian-Pliocene patches of red clays, stemming from weathered and redeposited Miocene tuffs, appeared as correlative sediments of periodical uplift, exhumation and pedimentation under subtropical conditions (7.5-3.7 Ma). In the Pleistocene both sheet wash and stream erosion were active under alternating warmwet, warm-dry, cold-wet and cold-dry spells (Székely 1973). Stream erosion was predominant in warm-wet phases causing an increase in slope angles, while sheet wash became common in warm-dry periods. In periglacial cold-wet and cold-dry phases however, gelisolifluction processes and gravitational talus creep moulded the surface (Marton-Erdös 2001), reducing slope angles.

\subsection{Landforms}

\subsubsection{Relief, valley density and slope inclination}

In order to understand the sources of landform diversity, a structural geological and engineering geomorphological approach should be combined with a comparative quantitative morphometric analysis of neighbouring landscapes. Based on the statements of Beavis (2000), who claims that geological structure determines the place, while lithology influences the extent of erosion, and Clayton and Shamoon (1998), who found that harder rocks statistically tend to support steeper slopes or higher landforms, we defined surface rock resistance to erosion (in $\mathrm{MPa}$ ) and the relationship between rock strength (as a lithological feature) and the selected morphometric features of landforms (Püspöki et al 2005). In general terms the horizontal and vertical dissection of a landscape may determine the character of positive landforms (Ollier 1967), and the calculated average values may be typical for the landscape. Two parameters, however, are not able to describe slope types (convex or concave), hence they cannot inform about the distribution of slope angles. Thus, apart from relative relief and valley density, slope angle frequency was also used as a distinctive morphometric feature (Demeter and Szabó 2008a) to estimate the extent of post-Miocene erosion in the Uppony Mountains and to compare the general character of landforms in different landscapes.

Although the correlations between valley density and relative relief $(r=0.83)$, relative relief and rock hardness $(\mathrm{r}=0.65)$, sloping and rock hardness $(\mathrm{r}=0.73)$, sloping and relative relief $(r=0.83)$ are not insignificant in the area (Fig. 20.5, A), the relationship between rock hardness and valley density in the Uppony Mountains proved to be weak $(r=0.4)$ (Demeter 
and Szabó 2008b). Since higher values of valley density and increased relief indicate uplifted areas, the dissected surface of the Uppony massif can be regarded as one of the most dynamic regions in North-Hungary. Nevertheless, in certain cases low relief may occur with higher valley density and high relief with lower valley density,, e.g. in the Aggtelek Karst).

Comparative studies show that the Szendrö Mountains, composed of the same rock types as the Uppony block, have lower valley density and relative relief (divergent evolution). Moreover, these values resemble those of the neighbouring Putnok Hills (composed of semiconsolidated Tertiary rocks), reflecting similar geomorphic settings (dissected planation surfaces in mountain forelands). The unconsolidated Pannonian sediments of the Cserehát (previously being an accumulation glacis of the Slovak Ore Mountains) form low ridges with wide valleys (mature phase). West of the Uppony Mountains, however, in the geologically homogeneous, but dissected Vajdavár Hills (Chapter 18), built up of consolidated Paleogene sandstones, higher elevations with steep slopes, similar to the features of the Uppony core, are predominant. Here convergent evolution (Lóczy 2008) based on rock strength can be suspected.

In the case of the Uppony Mountains a strong correlation was found between valley density and rock strength $(r=0.7)$ and also between rock strength and relative relief. But this relationship is not unambiguous. In the Börzsöny Mountains, for instance, there was no measurable correlation between relative relief and valley density either on schlieren or on andesites and tuffs, only on unconsolidated Pleistocene loess (Gábris 1987). Accordingly, both surface rock type and - beyond erosional valleys - the frequency of derasional valleys can influence this relationship. In addition, the increasing resistance of rocks led to the scarcity of derasional valleys $\left(r^{2}=-0.93\right)$ in Uppony.

High valley density in the Uppony massif reflects tectonic maturity. The horizontal dissection of the Paleo-Mesozoic-Neogene sedimentary area is similar to that of the North Hungarian volcanic ridge, namely the Visegrád $\left(2.9 \mathrm{~km} \mathrm{~km}^{-2}\right)$, Börzsöny $\left(2.8 \mathrm{~km} \mathrm{~km}^{-2}\right)$ and the Eastern Cserhát Mountains (3.1 km km${ }^{-2}$ ) (Ádám 1984). Nevertheless, if gullies (0-order valleys) are also included, even higher values are obtained for highly diagenized and semiconsolidated rocks (Paleo-Mesozoic siliciclasts: $4.3 \mathrm{~km} \mathrm{~km}^{-2}$, Paleogene sands and silts: 4.8 $\left.\mathrm{km} \mathrm{km}^{-2}\right)$. The lower density $\left(3 \mathrm{~km} \mathrm{~km}^{-2}\right)$ for Paleozoic limestones reflects continuous valley incision, while gullying remains to be of secondary importance. Terrains covered by old rocks are dominated by erosional valleys (Paleo-Mesozoic limestones: 66\%, Paleo-Mesozoic siliciclasts: 57\%), while gullies are predominant on Paleogene sandstones and Neogene marine sands and silts (46\% and 37\%). Present-day gullying is considerable: a comparison of land-use maps in three settlements between the 1860s and 1960s indicates intensive valley regression (exceeding $30 \mathrm{~m}$ in 15 cases out of 51) and deposition in some instances (3/51) indicating derasional processes, the most common on loose Paleogene and Neogene deposits (constituting 37\% and 26\% of the valleys, resp.) (Demeter and Szalai 2004).

Several authors pointed out the tectonic character of valleys in the Uppony Mountains. According to Schréter (1945), the Lázbérc reservoir is located along a transverse (NNW-SSE) fault. Pantó (1954) recognised intensive tectonism and planes of weakness in rocks. Peja (1956a, 1956b) regarded the Bán valley to be tectonically preformed. Dér (1957) proved that valleys are formed perpendicular to the strike on harder rocks (being the shortest way of runoff) and parallel to it on rocks of medium resistance. Láng (1953) identified asymmetrical valleys with usually shorter and steeper northwestern and longer and gentler southeastern slopes. Szalai (2004) confirmed that this phenomenon is regular in tectonically preformed valleys along the main faults where strata outcrop, but atypical in the case of transverse faults (see the Rágyincs Valley as an example) and that the directions of faults, fractures and valleys are in harmony (Fig. 20.6.). 
According to Szalai (2004), almost all valleys in the Uppony block are tectonically preformed, with $35 \%$ following major faults $\left(60^{\circ}\right)$ and steep thrust sheets with NNW vergence. Here in the massif the consequently parallel, northeast to southwest strike marks the direction of the reverse faults perpendicular to the direction of compression. To transversal faults $\left(325^{\circ}\right) 22 \%$ of the valleys are connected. Due to spatial shortening (in addition to foliation) a diagonal fault system also appeared (43\%) in the region. On the Tertiary molasse sediments, however, valley directions vary more considerably because of the dispersed fault lines and widespread derasional processes.

The harmful effects of the erosion still apparent on the terrain were mentioned as early as in 1777 in a questionnaire (Csorba and Tóth 1991). Variations in rock type and erosional resistance influence cumulative slope steepness, which is high in the Uppony massif: above 1500 points (out of 2500), whereas it is around 700 in the Cserehát Hills, 1100-1200 in the Szendrö Mountains and the Putnok Hills, 1200 points in the Aggtelek Mountains and the Pétervására Hills (Félegyházi et al 1999). On Neogene andesites (20 MPa), Neogene silts and Paleogene sands and clays (7 MPa) most common slope steepness is around 10-14\%, while on Paleozoic rocks (80-150 MPa) values around 24-26\% are typical. To quantify the resistance of different rocks to selective denudation, downwearing or valley regression, hypothetical slope profiles are presented here using the frequency $(\%)$ of slope intervals and slope angle. The width and relative elevation of identical features developed on different rocks was estimated (Fig 20.5, B and C).

\subsubsection{The Uppony Gorge}

The Csernely stream has been undoubtedly an important factor in geomorphic evolution of the region. After cutting across the whole mountains, it takes a sudden turn and carves the $500 \mathrm{~m}$ long, breathtaking Uppony Gorge (Fig. 20.3, 20.7) and finally joins the Bán stream. It is one of the most spectacular and deepest $(170 \mathrm{~m})$ gorges in Hungary and stretches from Uppony to Dédestapolcsány, exposing the geological structure of the old block. The Paleozoic limestones, schists and clay shales are exposed on the shores of the Lázbérc reservoir. On a nearly 4-km long nature trail one can get a unique experience by learning about the paleoenvironment of $140 \mathrm{Ma}$ (from the Silurian to the Carboniferous). The now abandoned manganese and iron ore mines were worked in the $18^{\text {th }}$ century for the smelters established by Heinrich Fassola. Cut into the Paleozoic shales, they - beyond their cultural values - also reveal geological structure, tectonics and stratification (Fig. 20.4).

In the moderately soluble, steep limestone cliffs of the Uppony Gorge 25 small caves, rock shelters and hollows have been registered. From one of these cavities, only some metres in length, Uppony niche no 1, an abundant set of Pleistocene paleonthological finds (e.g. bats and rodents) was discovered (Pazonyi and Kordos 2004). The gorge is also extremely rich in rare plants and such a great biodiversity in a small area can hardly be observed elsewhere in Hungary. On the hot rock swards of the Uppony Gorge of southern exposure, species of Mediterranean flora live whereas in the northern-exposed cold grasslands, on debris slopes and in shrub forests an assemblage characteristic of cool mountainous areas has developed. Among the cultural monuments, on top of the picturesque cliff marking the entrance to the gorge (Kalica) a cross symbolizes the boundary between Protestantism and Catholicism, while the forgotten ruins of the Dedevár castle remind us of the Middle Ages.

\subsubsection{The Rágyincs Valley}

Located in the southeastern part of the Uppony block (near Dédestapolcsány) the Rágyincs Valley is an excellent example of accordant drainage evolution. Along an almost 3-km-long 
easy walk along the path in the valley, one can observe the most significant geological and geomorphological forms and processes of the Uppony Mountains. On the conveniently accessible catchment area of the Rágyincs Stream - starting from the mouth at the southern bank of the Lázbérc reservoir and moving towards the source - one can discover exposures demonstrating microtectonic fracture system and lithological characteristics of the Paleozoic Tapolcsány Formation, Lázbérc Formation and Rágyincsvölgy Sandstone (Fig. 20.8), together with different stages and morphofacies of valley development, not to mention a rock arch. The short stream changes its character more than once along the course, forming a valley rich in geomorphological features (alluvial fan, meandering, terraces, rock channel, gorge, rock cliff, debris cone etc.) (Fig. 20.8).

With the help of valley cross-sections in different rocks or structural units typical landform groups were classified into morphofacies and extended to other parts of the Uppony Massif (Szalai 2004). Valley sections along imbrications, in the foreground of reverse faults, are common in the Uppony massif and have asymmetrical valley profiles. Characteristically, the channel is asymmetrical and the stream undercuts the front of imbricate structures, uncovering the bassets, while alluvium is deposited on the dip slopes, bedding planes (Fig. 20.8). Relatively stable, gently sloping surfaces (sometimes with soil creep) occur here. Mainly asymmetrical terraces show steps. The fronts, in contrast, are being continuously denuded into steep valley walls and convex slopes shaped by mass movements often form near the valley floor (Fig. 20.8).

Deeply incised along transverse faults, streams could have been redirected from one structural strip to another. Rocks of considerable resistance withstand erosion for long periods causing alluvial deposition in the headwaters. However, after the waterfalls are cut through, fast downcutting and the sudden removal of the deposited alluvium occurs, accompanied by the formation of terraces, almost symmetrical valley profiles, weathered-out ridges and bedrock channels in the upper valley sections.

Valley sections following the diagonal fracture system are transitional features between valleys preformed on the front of reverse faults and valleys running along transverse faults. This refers to the fact that stream erosion could easily cut diagonal fractures parallel with the main tectonic lines. Consequently, they could take part in preforming the imbricate structure or in maturing cut-throughs. The standard variation of symmetry index values is high.

\subsubsection{The Damasa Gorge and the Nagybarca Landslides}

For the density of mass movements, the Uppony Mountains do not exceed the Hungarian average with their 5-10 movements per $\mathrm{km}^{2}$. In the surroundings only the Ózd-Egercsehi Basin showed higher values due to subsurface mining. Around $50-75 \%$ of these movements were induced by human activity and similarly to the regional average, 25-50\% are considered to be active (Szabó 1996). The area of 50-75\% of all mass movement sites exceeds $250 \mathrm{~m}^{2}$. Being tectonically preformed, composed of rocks of different consistency and surrounded by uplifting horsts, the valley of the Bán stream - leaving the Paleozoic block behind - is ideal for observing characteristic landslides. The Damasa Gorge near Bánhorváti was formed by blocky landslides (quite rare in the country) induced by successive earthquakes in the $18-19^{\text {th }}$ century $(1763,1829,1834,1848)$. Two major blocks of the Sarmatian volcanic andesite agglomerate nappe slid on the underlying unconsolidated Badenian clayey marine sediments (often impregnated by water) that functioned as a slip plane, and created a 170-m deep and long gorge, where the average air temperature does not exceed $0^{\circ} \mathrm{C}$ even in summer (Hevesi 2006). The second biggest continuous network of non-karstic pseudocaverns of Hungary are found under these boulders. Additionally, rock shelters, outcrops and cliffs appear on andesitic rocks formed by exogenic processes (Fig. 20.9). 
Near Nagybarca, close to the remarkable outcrop of Csiga-teto" (where the Miocene crossbedded coastal dunes and Ostrea fauna are exposed), an older and mature landslide can also be found. The so-called 'Tó-lápa' was formed on unconsolidated sediments (Fig. 20.9). Intense valley incision led to more than $200 \mathrm{~m} \mathrm{~km}^{-2}$ relative relief values in the vicinity. This landslide-type is quite common in the country, but rare in the Uppony region. Its considerable(?) relative age is indicated by the fact that 3 out of 7 small sag ponds have disappeared by now confirmed by the vegetation cover and a comparison of old maps (Hevesi 2006).

\subsection{Conclusions}

The presented unique (both natural and semi-anthropogenic) features of geomorphological interest in the Damasa Gorge (landslides, pseudo-caverns), Rágyincs Valley (terraces, scarps, outcrops) and Uppony Gorge (karren, outcrops, cliffs, caves, mines, castle ruin) confirm the results of the general numeric and comparative analysis. High petrophysical diversity and an intricate geological structure contributed to the geomorphic diversity of the Uppony Mountains and reveal $300 \mathrm{Ma}$ of cyclic sedimentary and orogenic history in situ. The numeric analysis proved that not only the harder rocks, but steeper slopes, greater valley density and higher relief make this small area - surrounded by gentle hills of similar elevation resembling low mountains. The relationships between valley directions, slope morphology (valley asymmetry) and the occurrence of fault types were also verified. Prominent features built up of different rocks tend to have different shapes. Examples of convergent and divergent geomorphic evolution were also detected through a regional comparison of physical features, and the rate of recent valley regression was also measured.

\section{Acknowledgement}

This study has been supported by the Bolyai János Research Scholarship of the Hungarian Academy of Sciences.

\section{References}

Ádám L (1984) Az Észak-magyarországi-hegyvidék alakrajzi jellemzése (Morphography of the North Hungarian Mountains). Földrajzi Értesítő 33:321-332 (in Hungarian)

Árkai P, Horváth Z, Tóth M (1982) Transitional very low- and low-grade regional metamorphism of the Paleozoic formations, Uppony Mountains, NE-Hungary: Mineral assemblages, illite-crystallinity, $-\mathrm{b}_{0}$ and vitrinite reflectance data. Acta Geologica Academiae Scientiarum Hungaricae 24(2-4):265-294

Beavis SG (2000) Structural controls on the orientation of erosion gullies in mid-western New South Wales, Australia. Geomorphology 33:59-72

Budai T, Konrád Gy (2011) Magyarország földtana (Geology of Hungary). On-line Edition. Faculty of Sciences, University of Pécs, Pécs (in Hungarian)

Budinszkyné Szentpétery I, Kozák M, Less Gy, Müller P, Pelikán P, Pentelényi L, Peregi Zs, Prakfalvi P, Püspöki Z, Radócz Gy, Tóthné Makk Á, Földessy J, Zelenka T (1999) The Uncovered Geological Map of the North Hungarian Mts. MÁFI

Clayton K, Shamoon N (1998) A new approach to the relief of Great Britain II. A classification of rocks based on relative resistance to denudation. Geomorphology 25:155171 
Csorba Cs, Tóth P (eds) (1991) A Mária Terézia kori úrbérrendezés 9 kérdőpontos vizsgálatai (The 9-questions investigations on the duties and obligations of copyholders - serfs and villeins - in the era of Marie Therese). Borsod 1770. Miskolc (in Hungarian)

Demeter G, Szalai K (2004) Connection between land-use changes and erosional (derasional) valley development during the last 300 years in a model area. In: Anthropogenic aspects of landscape transformations, Debrecen 3:45-55

Demeter G, Szabó Sz (2008a) Quantification of relationships between geomorphic and geologic parameters representing rock resistivity (erodibility) in N-Hungary using statistical surface analysis. Acta Silesiana 3:5-13

Demeter G, Szabó Sz (2008b) Morfometriai és litológiai tényezők kapcsolatának kvantitatív vizsgálata a Bükkben és északi előterén. A statisztikus (felszín)elemzés alkalmazásának lehetőségei a geomorfológiában (A quantitative analysis of relationship between morphometric and lithological factors in the Bükk Mountains and its northern foreland. Opportunities for statistical terrain analysis in geomorphology). University of Debrecen, Debrecen, $182 \mathrm{p}$ (in Hungarian)

Dér I (1957) Az Upponyi Csermely-völgy víztározással kapcsolatos földtani szakvéleménye (Geological expert's report on water storage in the Csermely Valley, Uppony). In: Vitális Gy, Dér I, Zeller J (eds), Tájékoztató szakvélemény a Csermely patakon Uppony község határában létesítendő völgyelzárásról (Information on the valley impoundment planned on the Csermely Stream at Uppony). Manuscript. É. M. Mélyépítési Tervező Vállalat, Budapest. Archive of the Geological Institute of Hungary, Budapest, T. 2355. (in Hungarian)

Félegyházi E, Kiss T, Szabó J (1999) Természetföldrajzi gyakorlatok (Practice in physical geography). University notes. Kossuth Egyetemi Kiadó, Debrecen. 170 p (in Hungarian)

Gábris Gy (1987) Néhány gondolat a vízhálózatsűrűséget meghatározó tényezők vizsgálatáról (On the study of factors controlling drainage density). Földrajzi Közlemények 35:26-34 (in Hungarian)

Hevesi A (1986) A Bükk hegység felszínfejlődése és karsztja (Geomorphic evolution and karst of the Bükk Mountains). Manuscript CSc Thesis. Geographical Research Institute, Hungarian Academy of Sciences, Budapest, 187 p (in Hungarian)

Hevesi A (2006) Jellegzetes hegy(lejtő)csuszamlások a Bükkháton és az Upponyi-hegységben (Typical landslides in the Bükkhát and Uppony Mountains). Third Hungarian Geographical Conference, Debrecen, CD. 7 p (in Hungarian)

Kovács S (1994) Upponyi paleozóos rétegösszlet (The Uppony Paleozoic sequence). In: Fülöp J (ed.): Magyarország geológiája. Paleozoikum II (Geology of Hungary. Paleozoic II). Akadémiai Kiadó, Budapest, 66-118 (in Hungarian)

Láng S (1953) Természeti földrajzi tanulmányok az Észak-magyarországi középhegységben (Physical geographical studies in the North Hungarian Mountains). Földrajzi Közlemények 78(1-2):21-64 (in Hungarian)

Lóczy D (2008) Konvergencia-jelenségek a geomorfológiában (Convergence phenomena in geomorphology). In: Szabó J, Demeter G (eds), Geographia generalis et specialis. University of Debrecen, Debrecen, 69-77 (in Hungarian)

Marton-Erdős K (2001) Magyarország természeti földrajza (Physical geography of Hungary). 3rd Edition. University of Debrecen, Debrecen, 245 p (in Hungarian)

Ollier CD (1967) Landform description without stage names. Australian Geographical Studies $5: 73-80$

Pantó G (1954) Bányaföldtani felvétel az Upponyi-hegységben (Mine geological survey in the Uppony Mountains). Annual Report of the Geological Institute of Hungary for 1952, Budapest, 91-111 (in Hungarian) 
Pazonyi P, Kordos L (2004) Late Eemian (Late Pleistocene) vertebrate fauna from the Horváti-lik (Uppony, NE-Hungary). Fragmenta Palaeontologica Hungarica 22:107-117

Peja Gy (1956a) Tektonikus eredetű morfológiai formák kialakulása a Sajó-völgy középső szakaszának környékén (Development of morphological features of tectonic origin along the Middle Sajó Valley). Földrajzi Közlemények 80:365-380 (in Hungarian)

Peja Gy (1956b) Suvadástípusok a Bükk északi (harmadkori) előterében (Types of slumps in the norhern (Tertiary) foreland of the Bükk Mountains). Földrajzi Közlemények 4:217240 (in Hungarian)

Pelikán P (ed.) (2005) A Bükk hegység földtana. Magyarázó a Bükk-hegység földtani térképéhez (1:50 000) (Geology of the Bükk Mountains. Memoir to the geological map at 1:50,000). Geological Institute of Hungary, Budapest, 218 p (in Hungarian)

Péró Cs (1997) Prekambrium-Ópaleozoikum I (Precambrian-Early Paleozoic I). In: Karátson D (ed.): Magyarország földje. Kitekintéssel a Kárpát-medence egészére (The land of Hungary with an outlook to the whole Carpathian Basin). Magyar Könyvklub, Budapest, 84-90 (in Hungarian)

Püspöki Z (1998) Bádeni üledékek rétegtani jellemzői és határproblémái Uppony É-i elöterében (Stratigraphy and boundaries of Badenian sediments in the northern foreland of Uppony) Acta Geographica ac Geologica et Meteorologica Debrecina 34:281-304 (in Hungarian)

Püspöki Z, Szabó Sz, Demeter G, Szalai K, McIntosh RW, Vincze L, Németh G, Kovács I (2005) The statistical relationship between unconfined compressive strength and the frequency distributions of slope gradients. A case study in Northern Hungary. Geomorphology 71:424-436

Püspöki Z, Tóth-Makk Á, Kozák M, Dávid Á, McIntosh RW, Buday T, Demeter G, Kiss J, Püspöki-Terebesi M, Barta K, Csordás Cs, Kiss J (2009) Truncated higher order sequences as responses to compressive intraplate tectonic events superimposed on eustatic sea-level rise. Sedimentary Geology 219:208-236

Schréter Z (1945) Uppony, Dédes és Nekézseny, továbbá Putnok vidékének földtani viszonyai (Geology of the Uppony, Dédes, Nekézseny and Putnok area). Annual Report of the Geological Institute of Hungary for 1941-42, Budapest 1:161-195 (in Hungarian)

Szabó J (1982) A természeti környezet mezőgazdasági szempontú minősítése a Csereháton (Reprezentatív vízgyüjtő területek néhány ökológiai tényezőjének feldolgozása alapján) (Agricultural land evaluation in the Cserehát Hills based on the study of selected ecological parameters on representative catchments). Földrajzi Közlemények 31:255-284 (in Hungarian)

Szabó J (1996) Csuszamlásos folyamatok szerepe a magyarországi tájak geomorfológiai fejlödésében (The role of landslides in the geomorphic evolution of landscapes in Hungary). DSc Thesis. Kossuth Egyetemi Kiadó, Debrecen, 223 p (in Hungarian)

Szalai K (2004) Geomorfológiai vizsgálatok az Upponyi-szigethegységben és előterein, különös tekintettel a földtani adottságok szerepére (Geomorphological investigations in the Uppony Mountains with special regard to the significance of geological conditions). Manuscript PhD Thesis. University of Debrecen, Debrecen, $110 \mathrm{p}$ (in Hungarian)

Székely A (1973) A Magyar-középhegyvidék negyedidőszaki formái és korrelatív üledékei (Quaternary landforms and correlative sediments in the Hungarian Mountains). Földrajzi Közlemények 97:185-203 (in Hungarian)

Figures

Fig. 20.1 Geological and contour map of the area indicating sites of geomorphological interest (geology after Budinszkyné et al. 1999) 


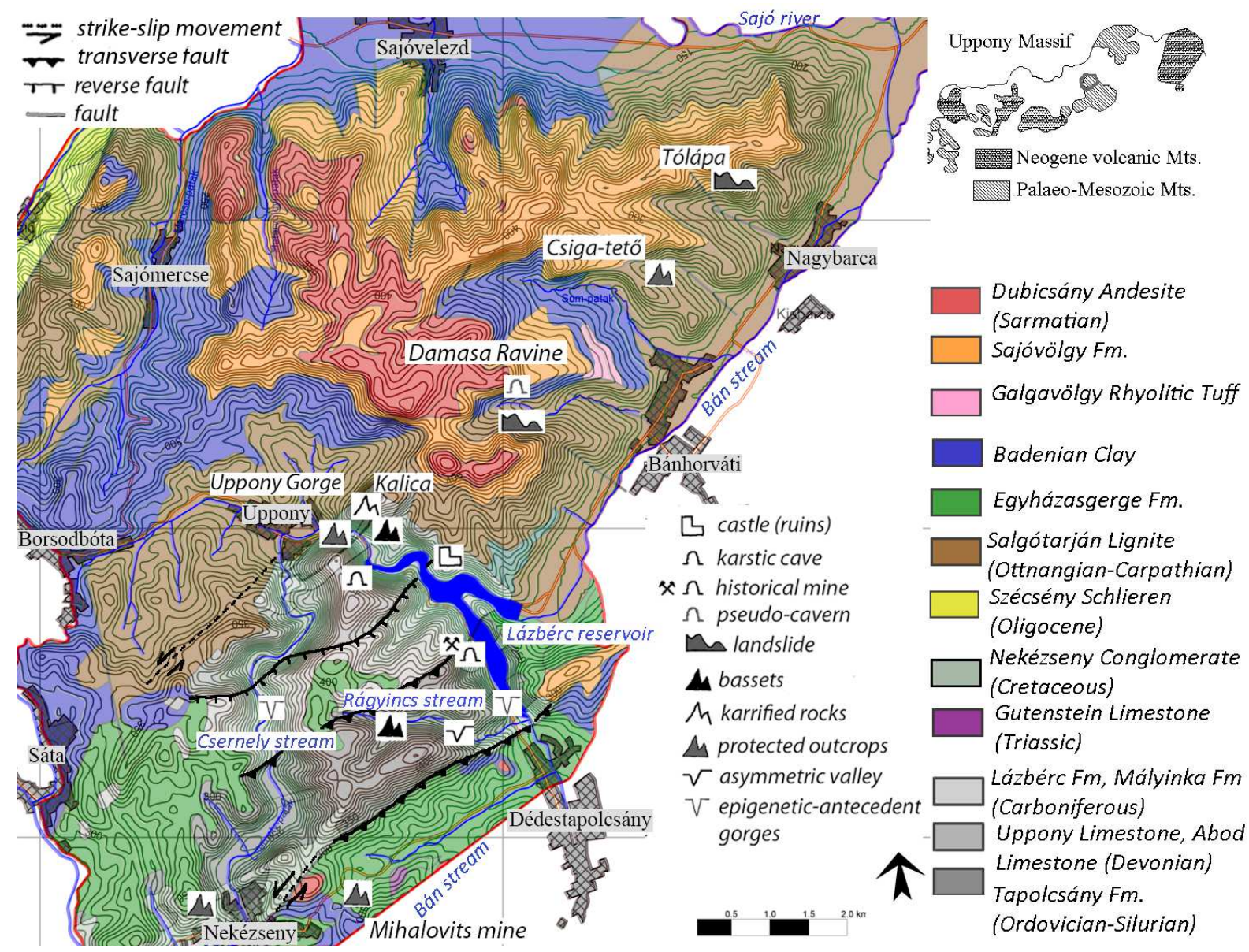

Fig. 20.2 Deep borehole Uppony-12 indicating the upthrust of basement over Oligocene rocks and a geological cross-section crossing the Uppony Massif (modified after Püspöki et al. 2009)

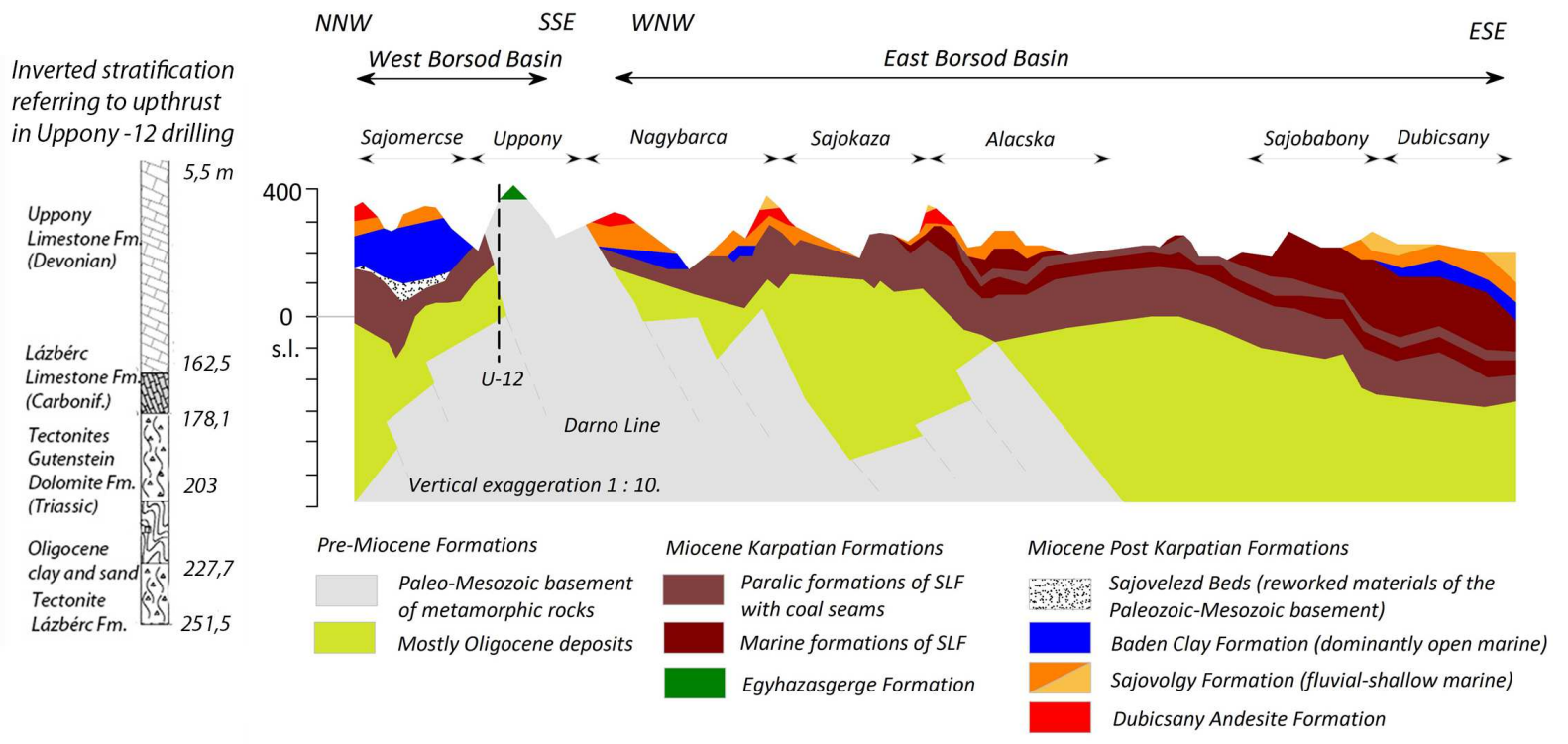

Fig. 20.3 The Uppony Gorge (Photos by Katalin Szalai)

The Uppony massif and its semi-consolidated foreland (A) 
The karstic horst of Mt. Kalica composed of Palaeozoic limestones guards the entrance of the Uppony Gorge (B)

The artificial Lázbérc reservoir is located in a tectonically preformed valley (C)

Karren on limestone bassets and caves on the opposite side of the Uppony Gorge with Uppony village in the background (D)

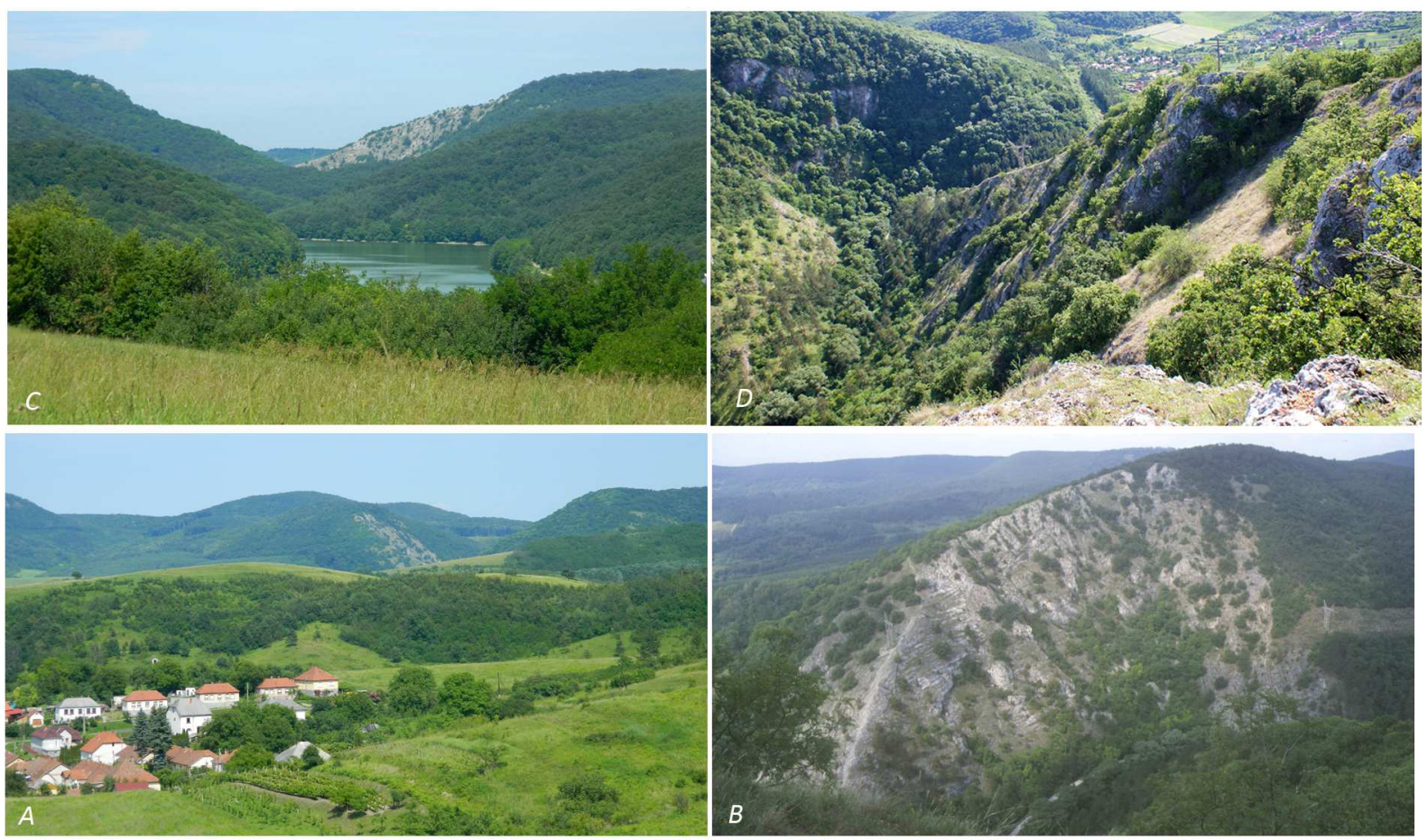

Fig. 20.4 Geological features observed in outcrops (pictures of the bottom row from Fülöp, 1994)

Imbrication in an outcrop near Uppony (A)

Tectonic movements resulted in the foliation of rocks (B)

Folded Palaeozoic limestone and shale joining along a fault plane (C)

Tunnel used to explore Fe and Mn ore (D) 

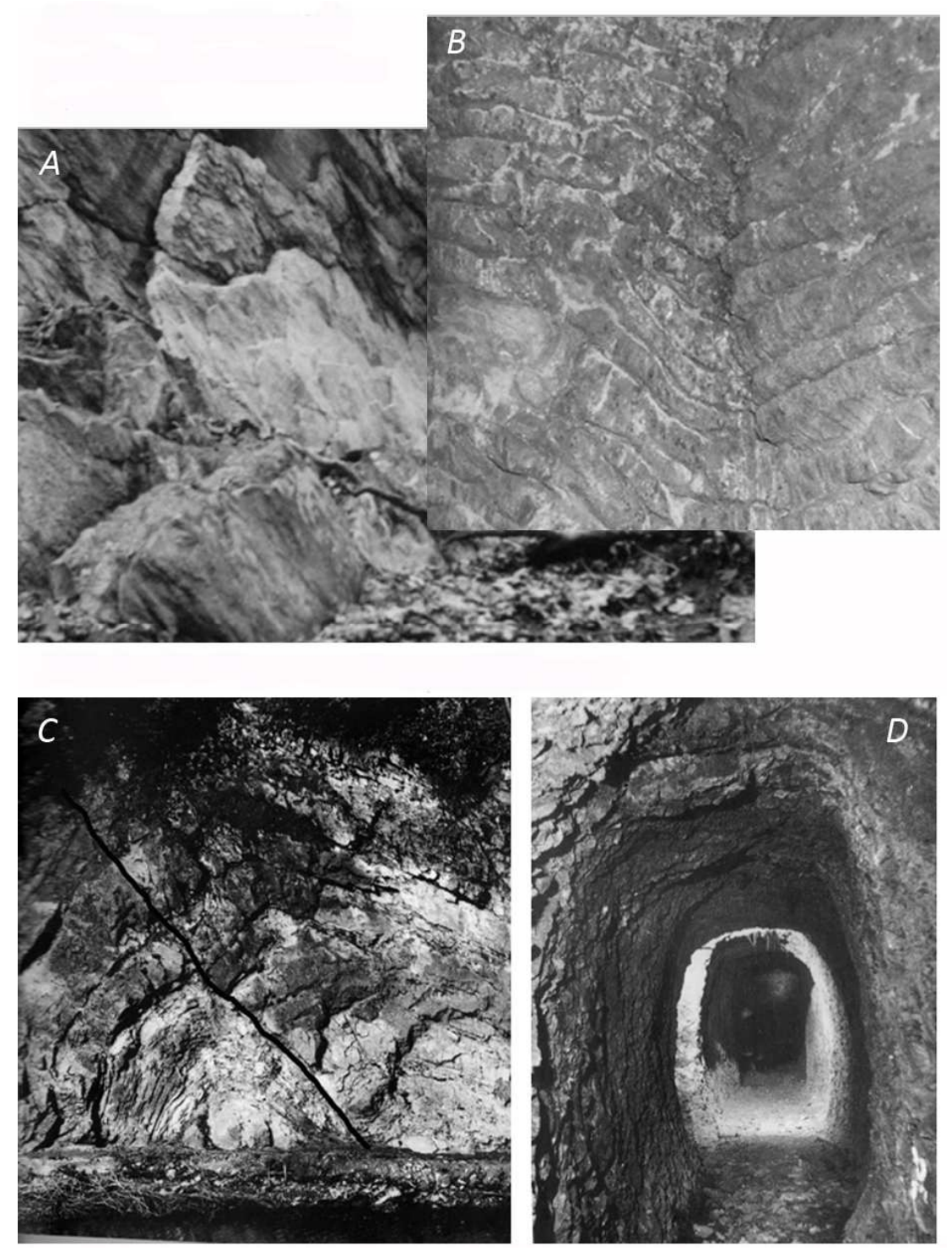

Fig. 20.5 Comparative geomorphology: regional differences in the extent of horizontal and vertical dissection (A) and the role of selective denudation on different rocks (B - height and $\mathrm{C}$ - width of landforms) 

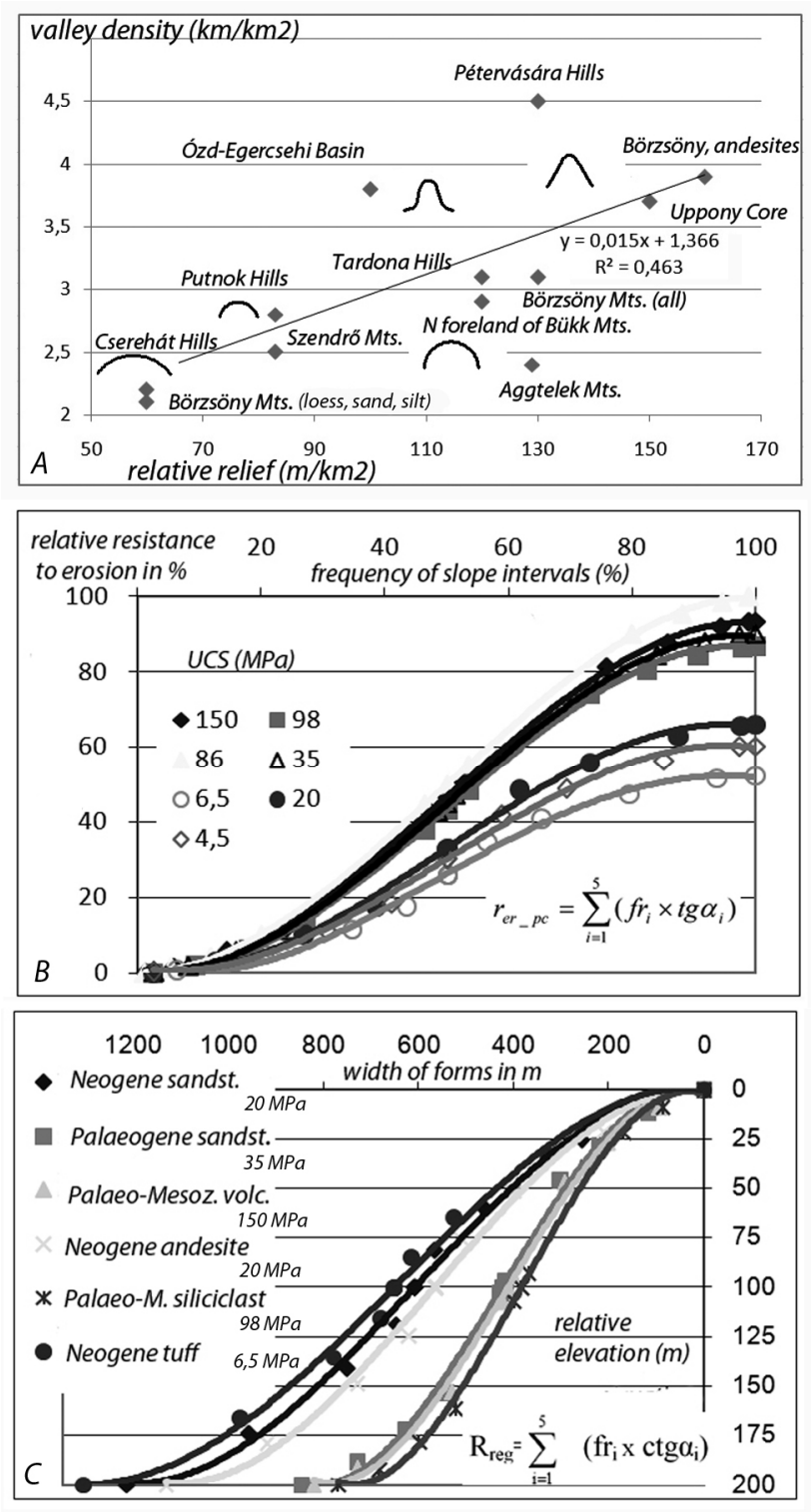

Fig. 20.6 Relationship between valley directions and distribution of faults

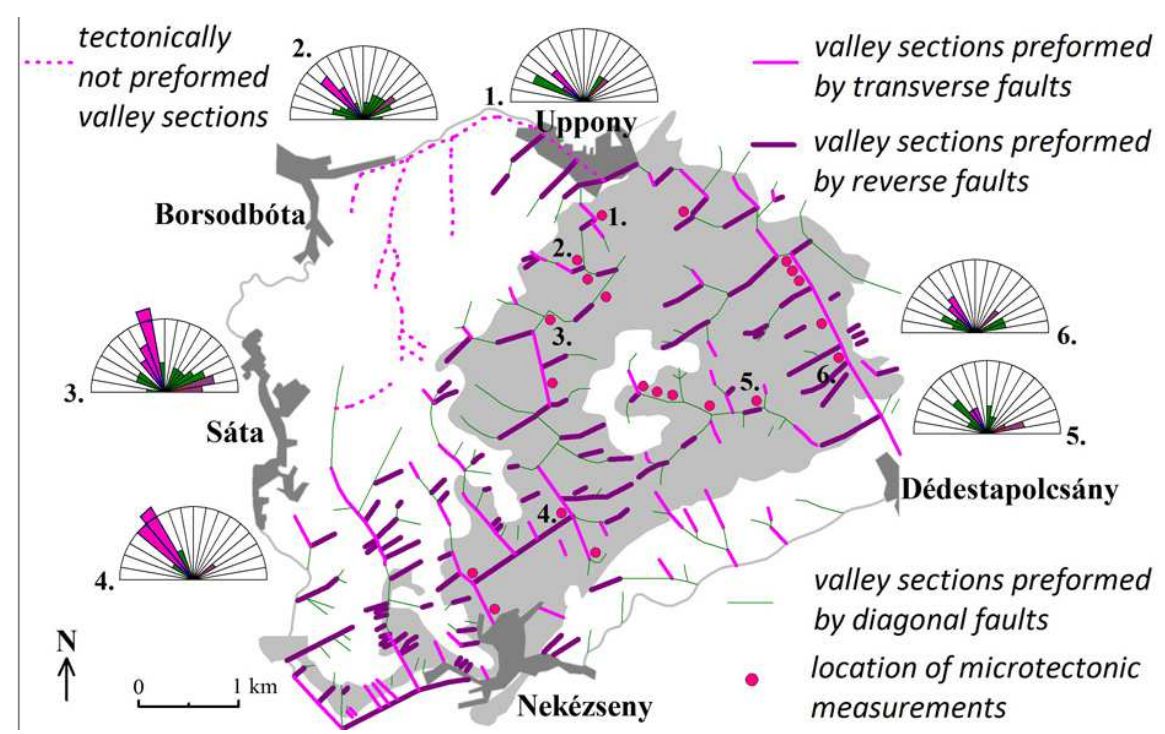


Fig. 20.7 Geomorphological map of the Uppony Massif and its surroundings (after Szalai 2004)
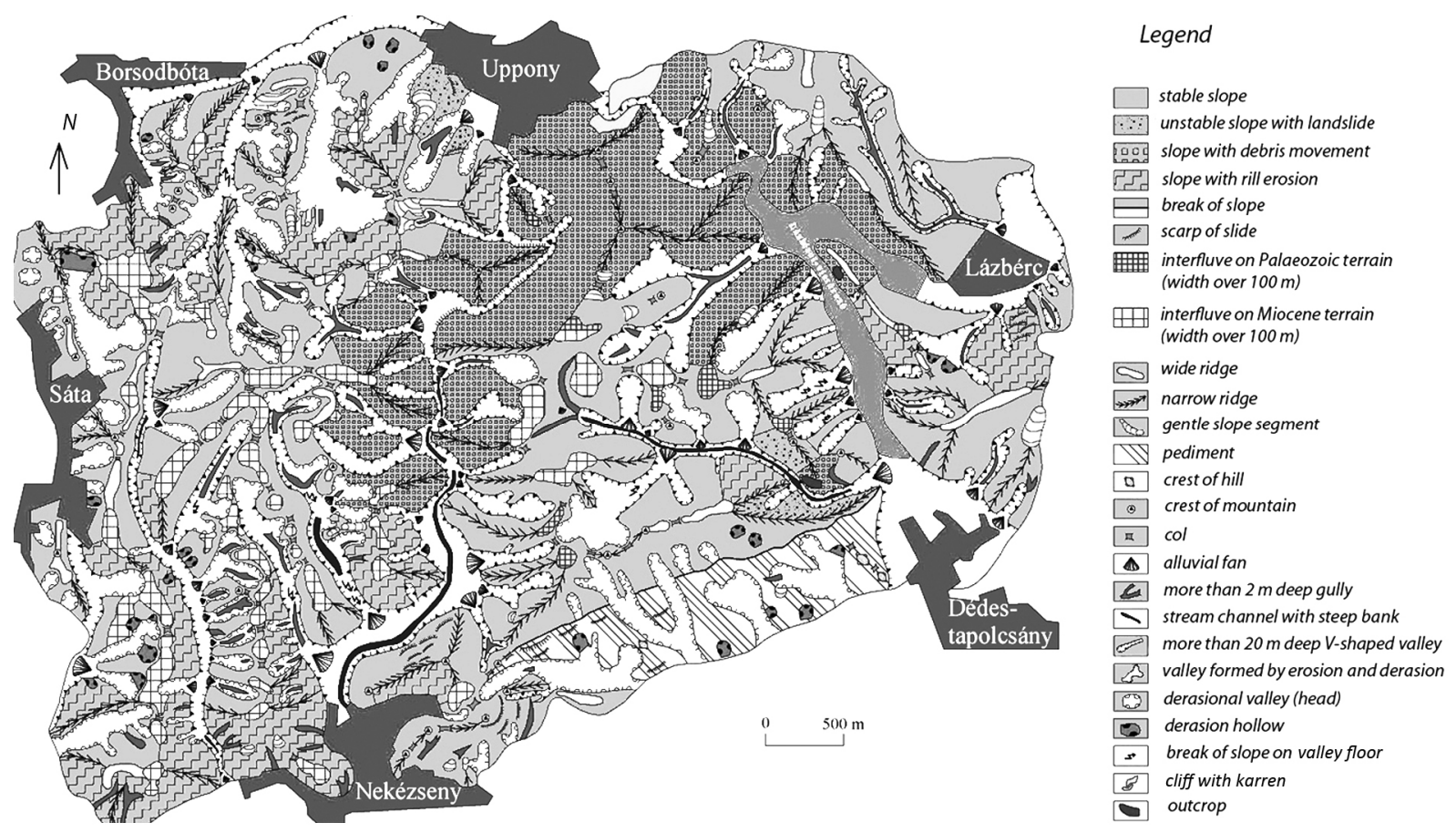

Fig. 20.8 Geomorphological features of the Rágyincs Valley

Valley profile on reverse fault in Rágyincs valley (A)

Geomorphology of the Rágyincs valley (B)

Where the stream cuts into the hard Rágyincsvölgy Sandstone, a gorge-like valley section with spectacular cliffs and a steep bedrock channel were formed (C and D). On less resistant rocks however (e.g. alluvium) the stream is meandering $(\mathrm{E})$ 

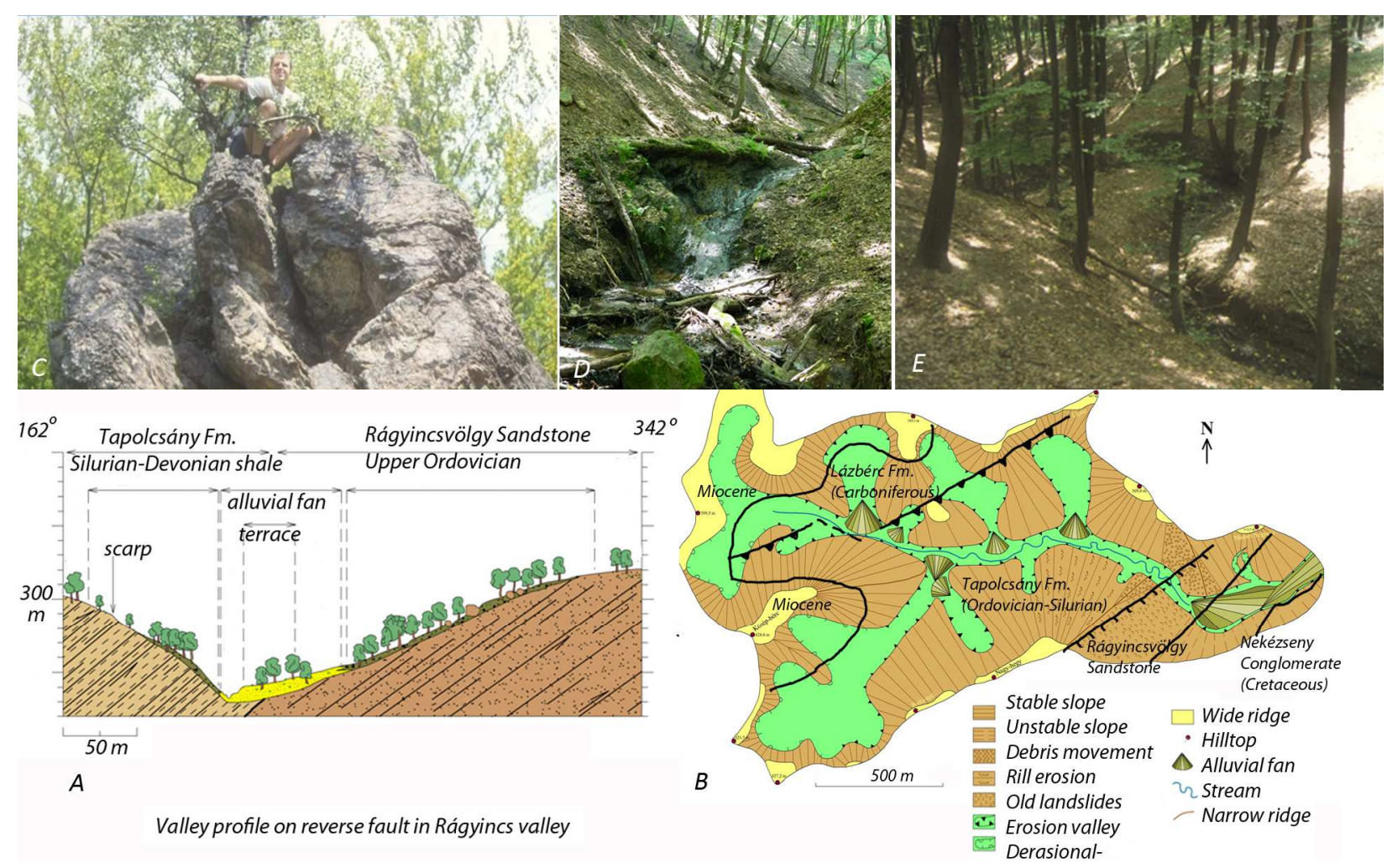

Fig. 20.9 Sketch of the Tó-lápa landslide at Nagybarca and the Damasa Gorge near Bánhorváti (Hevesi 2006)
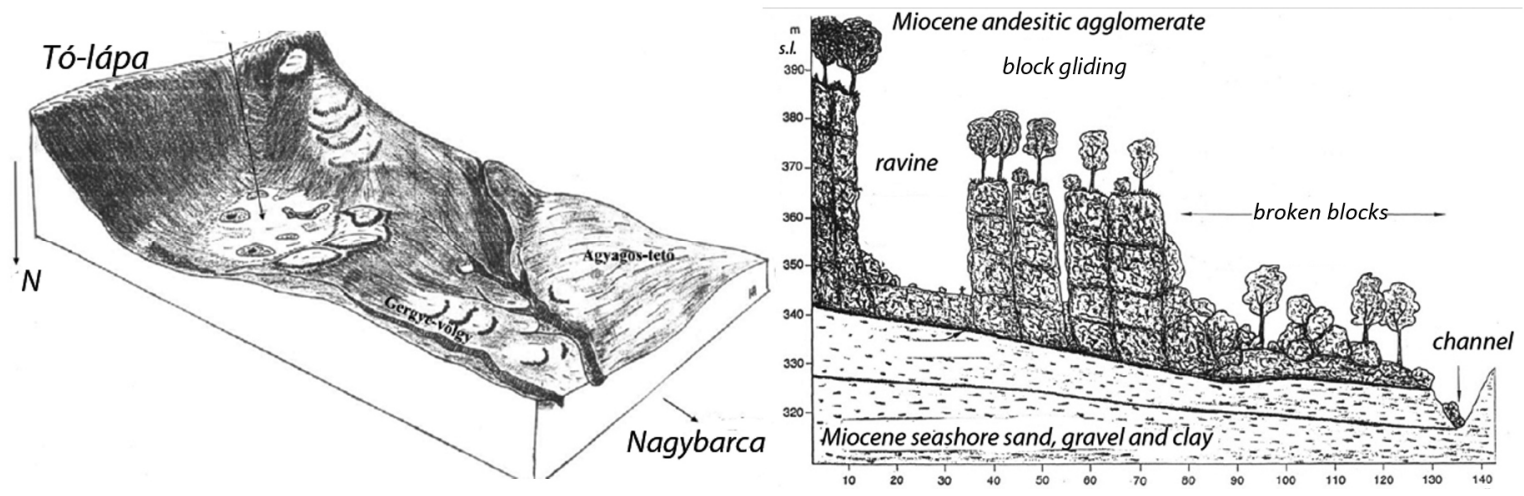